\title{
The Life Cycle and Sensitivity of the Local Copepod, Apocyclops sp to Tributyltin Exposure
}

\author{
Siklus Hidup dan Kepekaan Kopepoda Apocyclops sp Lokal terhadap Paparan \\ Tributiltin
}

\author{
Inneke F.M. Rumengan*, N.D. Rumampuk, D. Sumilat, J. Rimper \\ Fakultas Perikanan dan Ilmu Kelautan,Universitas Sam Ratulangi \\ Kampus Unsrat, Bahu, Manado 95115, Indonesia \\ E-mail: innekerumengan@hotmail.com *Penulis untuk korespondensi
}

\begin{abstract}
Abstrak
Uji toksisitas tributiltin secara akut telah dicobakan pada kopepoda tropis Apocyclops sp. yang diisolasi dari tambak Manembo-nembo Bitung, Sulawesi Utara. Kopepoda dikultur dalam kondisi laboratorium $\left(25-27^{\circ} \mathrm{C}, 30 \mathrm{ppt}\right.$ dan tanpa penerangan) dengan pemberian mikroalga Nannochloropsis oculata sebagai pakan. Semua individu kopepoda yang digunakan sebagai hewan uji berasal dari sepasang induk jantan dan betina. Kopepoda untuk eksperimen tributiltin (TBT) diberi perlakuan dalam air laut dan selama eksperimen tidak diberi pakan, dan larutan stok TBT-Cl dilarutkan dalam aseton. Pengaruh starvasi (tanpa pemberian pakan) dan aseton diamati sebelum uji toksisitas TBT dilakukan. Setiap eksperimen, 10 kopepoda dewasa (5 jantan dan 5 betina) dari satu kohort dimasukkan ke dalam cawan petri (diameter 3 cm) berisi masing-masing $10 \mathrm{ml}$ air laut. Ternyata perlakuan tanpa pemberian pakan tidak mempengaruhi kopepoda selama periode eksperimen. Dalam uji toksisitas TBT, hanya 3 individu yang dapat bertahan sampai akhir eksperimen (8 jam) walaupun dengan konsentrasi terendah $\left(0.0001\right.$ ng. $\left.^{-1}\right)$. Kebanyakan individu telah mati sebelum 8 jam diekspos ke konsentrasi TBT 0.01 ng. $^{-1}$. Pada konsentrasi TBT yang lebih tinggi (0.1 dan 1 ng. $^{-1}$ ), tingkat kelulusan hidup kopepoda hanya $50 \%$ dalam waktu kurang dari satu jam, sedangkan kopepoda yang sisa masih hidup semuanya sebelum mati jam ke-4 yang diberi perlakukan. Dalam uji toksisitas ini, semua konsentrasi yang dicobakan ternyata lebih kecil dari rata-rata konsentrasi TBT di alam (10 $\left.\mathrm{ng}^{-1}\right)$. Kisaran konsentrasi TBT yang lebih lebar masih perlu diuji-cobakan untuk mengklarifikasi efek akut TBT agar dapat diperoleh konsentrasi untuk uji toksisitas secara kronis.
\end{abstract}

Kata kunci: Kopepoda laut Apocyclops sp, efek akut, organotin, tribultiltin (TBT)

Diterima: 23 September 2008, disetujui: 20 Februari 2009

\section{Introduction}

Remarkable increase of TBT utilization has led to the environmental concern, in particular for the marine ecosystem. TBT is worldwide recognized as the most dangerous chemical ever introduced in large quantities in estuaries and coastal waters (Harino et al., 1998, 2003; Morabito and Quevauviller, 2002; Bekri and Pelletier, 2004). Application of TBT in ship paint as antifoulant may be the main source of TBT contamination in seawater. The consequence of the direct introduction into the marine environment and widespread of its toxicity to non-target aquatic animals such as mussels, clams, oysters, sea star, crustaceans and alga has been well documented (Morabito and Quevauviller, 2002; Ohji et al., 2002 a,b; EPA, 2003; Rumampuk et al., 2004a,b; Rumengan et al., 2008). 
Many studies on environmental impact of TBT have reinforced the need for the regulation of TBT usage. Regulation of restriction for TBT utilization in Indonesia has not been developed yet (Rumengan et al., 2008). Without further restrictions on the use of organotins and their entry into marine waters, it seems certain that the negative impact of organotins on biota will continue. As persistent compound, in seawater TBT could accumulate in sediment and biota, and magnify through marine food chain. Therefore, many studies are still needed to further illuminate the bioaccumulation or impact of organotins on marine life in Indonesia, not only for mollusks and fish, but also for other taxa including zooplankton.

Copepods are microcrustacean zooplankton which dominates up to $70 \%$ in most tropical coastal waters. This plankton plays an important role in marine food chain as primary feed for the higher animal taxa. Therefore, any adverse effects of pollutants on this zooplankton may lead to serious ecological consequences. In addition, if xenobiotic are bioconcentrated by copepods, it may potentially lead to food chain transfer or biomagnification. The degree to which TBT poses a threat to copepods in natural environment is necessary to assess. Data from laboratory experiments could provide both an estimate of toxicity and a comparable basis for establishing criteria of TBT safety levels. There is very limited data on toxicity effects of TBT on zooplankton compared to other aquatic organisms worldwide. As documented by EPA (2003), very limited number of copepod species Acartia tonsa and Eurytemora affinis, Nitocra spinipes, have been reported very sensitive to TBT. More recent data is necessary for other copepod taxa.

The aim of the present study was to examine the sensitivity of a local cyclopoid copepod to TBT exposure, and to observe the life cycle of copepods and their environmental condition requirement.

\section{Materials and Methods}

\section{Specimen preparation}

Cyclopoid copepods were collected from a brackish water pond in Manembo-nembo, Bitung, North Sulawesi. The copepods were cultured in laboratory condition $\left(25-27^{\circ} \mathrm{C}, 30\right.$ ppt, no illumination) fed with Nannochloropsis oculata. All copepod used was derived from one pair of spawner. Seawater for whole experiments was obtained from offshore of Manado Bay. Prior to TBT experiments, the life cycle of copepods was examined by individual culture. For each experiment, all individuals used were one cohort of mature copepods of two sexes which were distinguished based on the morphology (genital segment, caudal rami and body size). Whole experimental procedures were adopted from Ohji et al., 2002a,b.

\section{Preliminary tests}

Copepods for TBT experiments were treated in seawater without food. Therefore, an examination on the period of time (days) copepods could survive without food was conducted. Ten adults of copepods (5 males and 5 females) were put into each Petri dish (3 $\mathrm{cm}$ in diameter) with $10 \mathrm{ml}$ seawater. The copepods were observed under microscope until all organisms died (22 days).

Acetone was used as an organic solvent for TBT. In order to examine the effect of acetone, copepods were exposed to five concentrations of acetone $(0,0.0625,0,125$, 0.25 , and $0.5 \mathrm{ml}^{-1} \mathrm{l}^{-1}$ in seawater) without food. Ten individuals ( 5 males and 5 females) were put into each Petri dish containing $10 \mathrm{ml}$ of acetone-seawater solution. Each treatment was with 3 replicates. Observations were conducted until all copepod died.

\section{Sensitivity test}

TBT solution was prepared by initially diluted with acetone. The experimental TBT concentrations were $0.0001,0.001,0.01,0.1$ and $1 \mathrm{ng} . \mathrm{l}^{-1}$, which were prepared in natural sterilized seawater without algal suspension. For each treatment, there were 3 replicates, each one containing $10 \mathrm{ml}$ of experimental 
medium in a Petri dish, where 10 individuals of copepods (5 males and 5 females) were put into. The copepods were obtained from actively growing culture in $30 \mathrm{ppt}$ of seawater with Nannochloropsis oculata suspension. The observation was hourly conducted until all individual died.

\section{Results and Discussion}

Results of the preliminary observation that copepods Apocyclops sp and Calanus spp were predominantly found in Manembo-nembo brackish-water ponds, with density ranged from 2.25 to 16.81 inds/liter depending on lunar phase. However, only Apocyclops sp could survive in laboratory condition. Life cycle of the copepods as the other cyclopoid copepods, consists of six naupliars, four copepodid stages and two stages of adult. It required 10.5 and 9.6 days for male and female, respectively to develop from hatching to adult. Naupliar size varied from 100 to $375 \mu \mathrm{m}$ and copepodite from 425 to $825 \mu \mathrm{m}$. Adult female had larger body size $(1105.7 \mu \mathrm{m})$ than males $(943.3 \mu \mathrm{m})$. Reproductive age of female was 13-70 days old. The number of eggs in an ovisac was 8.2 to 11.4. In small scale culture trials, the population growth reached the maximum (65 ind. $\mathrm{ml}^{-1}$ ) after 39 days of culture period.

In the initial tests, as shown in Fig.1, under starvation condition, no copepods died until day 4. In all dish only one individual died after 4 days. At day 7 again one individual died. In average $50 \%$ survival rate was determined after 12-13 days. All individuals died after 22 days. It seems no effect of starvation on the copepods for at least 4 days. In general copepods are very strong, in condition without food. Similar tendency was found when copepods exposed to acetone. No copepods died after 11 days exposed to acetone with all concentration tested. In all dish only one individual died after 12 days. All individuals died after 29 days. It seems no effect of acetone of all concentration tested on the copepods for at least 11 days.

In the acute toxicity tests of TBT, although still very preliminary results, it can be seen in Fig. 2, the local copepods are very sensitive to TBT, even at TBT concentrations as ultralow as $0.0001 \mathrm{ng} . \mathrm{l}^{-1}$ they survived in very short time of exposure (less than 8 hours). While in the control no copepods died until the termination of experiment. When the copepods exposed to 0.1 and $1 \mathrm{ng} . \mathrm{l}^{-1}, 50 \%$ of the tested animals died in very short period of time $(<1$ hour). All individuals died after 4 hours exposure to higher concentration $(0.1$ and 1 ng. $\left.l^{-1}\right)$. All concentrations tested have caused $50 \%$ survival before 2 -h exposure to TBT. The LC50 values were at exposure time of less than 2 hours. In this experiment all concentration tested was far below the environmentally realistic concentrations of $10 \mathrm{ng}^{-1}{ }^{-1}$ (EPA, 2003).

In general, most other marine fauna including fish are more resistant to TBT than copepods (Hall et al., 1988). Even though, toxicity data with marine copepods are limited, but the available data (EPA, 2003) suggest that copepods are good indicator for assessment of TBT contamination in marine environment. The acute values of estuarine copepods, $E$. affinis and $A$. tonsa ranked very low with LC50

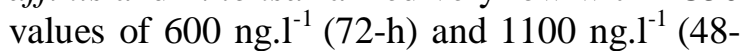
h). The other documented data of EPA (2003) shows lower LC50 for the 10-12 d old A. tonsa (240 ng. $1^{-1}$ ). This suggests that the local copepods are much more sensitive to TBT.

The sensitivity of copepods to TBT in bioassays should be evaluated by comparing the lowest observable effect concentration (LOEC) (EPA, 2003). Most antifouling compounds have the LOEC values of $\mathrm{ppb}$ levels, which represent the initial toxicity threshold of a chemical (Fernandez-Alba et al., 2002). Linley-Adam (1999) documented the information on the No Observed Effects Level (NOEL) of $1 \mathrm{ng} . \mathrm{l}^{-1}$ for phyto and zooplankton. Such a concentration is already lethal concentration to the local copepods. It is, therefore, necessary to determine both the LOEC and the no observable effect concentration (NOEC) in order to develop chronic toxicity test for the copepods. From the present results, the LOEC was not able to determine due to very short period of exposure time. The available data on TBT chronic values provided by EPA (2003) are very limited, only for some copepod species, all below $0.01 \mu \mathrm{g} .1^{-1}$. 
A. tonsa showed inhibition of development at $0.003 \mu \mathrm{g} . \mathrm{l}^{-}{ }^{1}$. Many reports demonstrate the reductions in growth occur in commercially or ecologically important marine species at concentrations of TBT less than the Final
Chronic Value of $0.0658 \mu \mathrm{g} . \mathrm{l}^{-1}$ (EPA, 2003). Survival of the copepod $A$. tonsa was reduced in $0.023 \mu \mathrm{g} .1^{-1}$. The sensitivity of Apocyclops sp in this study should be further examined by the chronic toxicity tests.

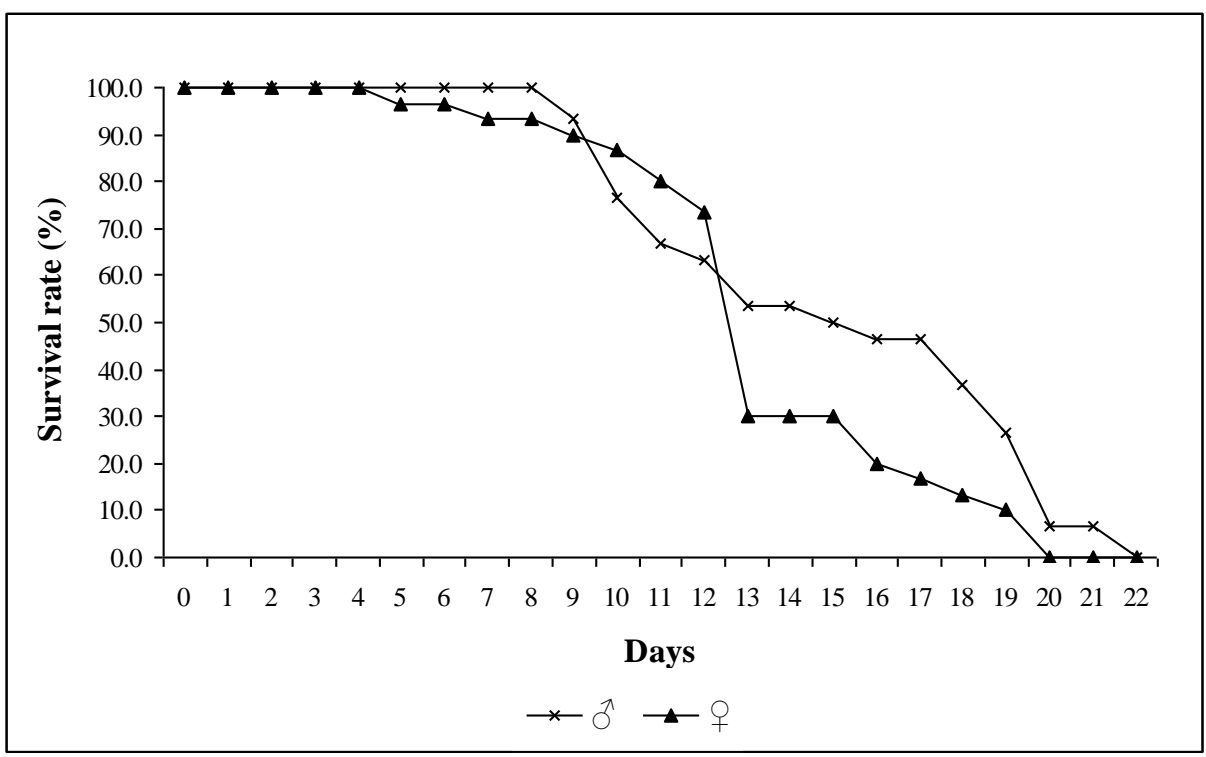

Fig.1. Survival rate of copepods under starvation condition.

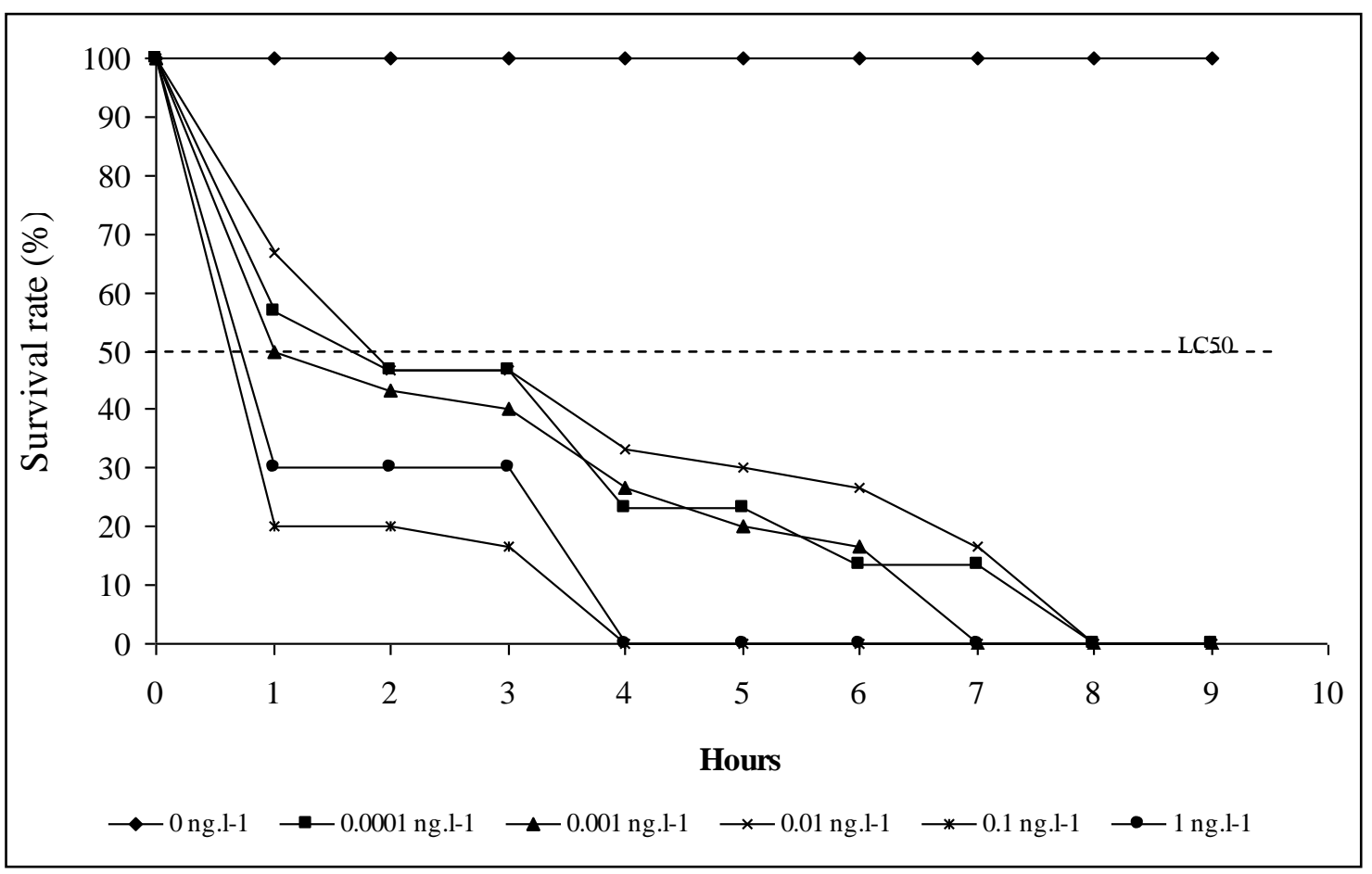

Fig. 2. Acute toxicity effects of TBT on survival rate of copepods. 


\section{Acknowledgements}

We appreciate very much for Dr. M. Ohji from Institute of Symbiotic Science and Technology, Tokyo University of Agriculture and Technology, Fuchu, Tokyo 183-8509, Japan, and for Dr. T. Arai of the International Coastal Research Center, Ocean Research Institute, The University of Tokyo, 2-106-1 Akahama, Otsuchi, Iwate 028-1102, Japan for providing us the TBT-Cl solution and technical information on preparation of TBT experiments.

\section{References}

Bekri, K. and Pelletier, E. 2004. Trophic transfer and in vivo immunotoxicological effects of tributyltin (TBT) in polar seastar Leptasterias polaris. Aquat. Toxicol. 66:39-53.

Environmental Protection Agency (EPA) 2003. Ambient aquatic life water quality criteria for tributyltin (TBT). Office of Water 4304T. US EPA 822R-03-031.

Fernandez, A.A.R., Hernando, M.D., Piedra, L. and Chisti, Y. 2002. Toxicity evaluation of single and mixed antifouling biocides measured with acute toxicity bioassays. Analytica Chimica Acta 456:303-312.

Hall, L.W., Bushong, S.J., Ziegenfuss, M.C. and Johnson, W.E. 1988. Chronic toxicity of tributyltin to Chesapeake Bay Biota. Water, Air, and Soil Pollution 39: 365-376.

Harino, H., Fukushima, M., Yamamoto, Y., Kawai, S. and Miyazaki, N. 1998. Contamination of butyltin and phenyltin compounds in the marine environment of Otsuchi Bay, Japan. Environmental Pollution 101:209-214.

Harino, H., Yamamoto, Y., Kawai, S. and Miyazaki N. 2003. Butyltin and phenyltin residues in water, sediment and biological samples collected from Otsuchi Bay Japan. Otsuchi Marine Science 28:84-90.
Linley-Adam, G. 1999. Harmful effects of the use of antifouling paints for ships. The accumulation and impact of organotins on the marine biota within the Mediterranean Region. International Maritime Organization Report. MEPC43/INF14.WPD. pp. 15.

Morabito, R. and Quevauviller, P. 2002. Performances of spectroscopic methods for tributyltin (TBT) determination in the 10 years of the EU-SM\&T organotin programme. Spectroscopy Europe 14/4. pp 18-23.

Ohji, M., Takeuchi, I., Takahashi, S., Tanabe, S. and Miyazaki. N. 2002a. Differences in the acute toxicities of tributyltin between the Caprellidea and the Gammaridea (Crustacea:Amphipoda). Marine Pollution Bull. 44: 16-24.

Ohji, M., Arai, T. and Miyazaki, N. 2002b. Effects of tributyltin exposure in the embryonic stage on sex ratio and survival rate in the caprellid amphipod Caprella danilevskii. Mar Ecol Prog Ser 235: 171-176.

Rumampuk, N.D.C., Rumengan, I.F.M., Ohji, M., Arai, T. and Miyazaki, N. 2004a. Effects of tributyltin pn the chlorophyll contents of marine microalga Tetraselmis tetrathele, Nannochloropsis oculata and Dunaliella sp. Coastal Marine Science 29 (1): 40-44.

Rumampuk, N.D.C., Grevo, G.S., Rumengan, I.F.M., Ohji, M., Arai, T. and Miyazaki, N. 2004b. Effects of triphenyltin exposure on the red alga, Eucheum denticulatum. Coastal Marine Science 29 (1): 81-84.

Rumengan, I.F.M., Ohji, M., Arai, T., Harino, H., Arifin, Z. and Miyazaki, N. 2008. Contamination status of butyltin compounds in Indonesian coastal waters: A Review. Coastal Marine Science 32 (1): 116-126. 